\title{
Independence of Brachymesophalangia-5 from Brachymesophalangia-5 with Cone Mid-5
}

\author{
STANLEY M. GARN, ANDREW K. POZNANSKI, JERROLD M. NAGY \\ AND MARY B. MCCANN \\ Center for Human Growth and Development and Department of Radiology, \\ The University of Michigan, Ann Arbor, Michigan 48104, and \\ Nutrition Program, Center for Disease Control, \\ Atlanta, Georgia 30333
}

KEY WORDS Bone · Fingers ' Phalanges · Radiograph Anomaly · Inheritance - Sex Differences

\begin{abstract}
Analysis of hand radiographs of juvenile siblings of juvenile propositi indicates that brachymesophalangia-5 alone (without cones) is separately inherited without apparent sex bias while brachymesophalangia-5 with the cone-epiphysis of mid-5 and the cone-epiphysis of mid-5 alone are both apparently inherited as a complex and with a marked excess of females over males.
\end{abstract}

Brachymesophalangia-5 is a not-uncommon variant of the hand skeleton with population frequencies ranging from below $1 \%$ to over $10 \%$ in different human groups (Garn, '71; Garn et al., '67; Hertzog, '67; Abbie, '70; Greulich, '70). Prior to complete epiphyseal union, brachymesophalangia-5 may also be associated with a peg-shaped or cone-shaped epiphysis (Hertzog et al., '68) and some authors have assumed a cone-epiphysis is subject to premature union and therefore leads to length restriction of the affected phalanx (cf. Giedion, '65; Caffey and Silverman, '67; de Iturriza and Tanner, '69).

The extent of association between brachymesophalangia-5 and a cone-epiphysis can best be ascertained in subjects large enough to evidence a well-developed epiphysis, yet prior to epiphyseal union. This we have done using radiographs of 8854 juvenile participants in the Ten State Nutrition Survey of 1968-1970 and limiting subjects to those between 3.5 and 12.0 years. Of the total number of children considered, 186 exhibited brachymesophalangia-5 and $51 \%$ of those affected were also characterized by a coneepiphysis, including the full cone-andcrater complex. Separately, 163 boys and girls evidenced a cone-epiphysis of mid-5 and $58 \%$ of those with cones also exhibited brachymesophalangia-5 (cf. table 1). Clearly, there is an association between the two variants with a larger proportion of those with cones showing brachymesophalangia-5 than vice versa.

A second approach to the association between brachymesophalangia-5 and the cone-epiphysis of mid-5 is through the siblings of affected propositi, noting whether the siblings of index cases tend to resemble the propositi. This we have also explored, first separating propositi with brachymesophalangia-5 alone, from those with the cone-epiphysis alone, and both groups of propositi from those with the combination brachymesophalangia-5 and cone-epiphysis mid-5 (see fig. 1). As explained above, both propositi and siblings were restricted to the age limits 3.5 to 12.0 , no propositus was used more than once, and only sibships with one or more siblings in the designated age range were considered. This sibling analysis proved especially revealing, because brachymesophalangia-5 alone segregated out separately from cones-alone and the combination of brachymesophalangia and cones.

To begin with, 109 siblings of 49 propositi with brachymesophalangia alone evidenced a far higher incidence of the short middle phalanx (11\%) than in the population sample considered $(2.1 \%)$, a difference significant at any reasonable level of confidence. Of even greater interest, the 12 affected siblings of propositi with brachymesophalangia alone were largely of the variant brachymesophalan- 
TABLE 1

Brachymesophalangia-5 and cone-epiphysis-5 in the survey population and in the siblings of affected propositi

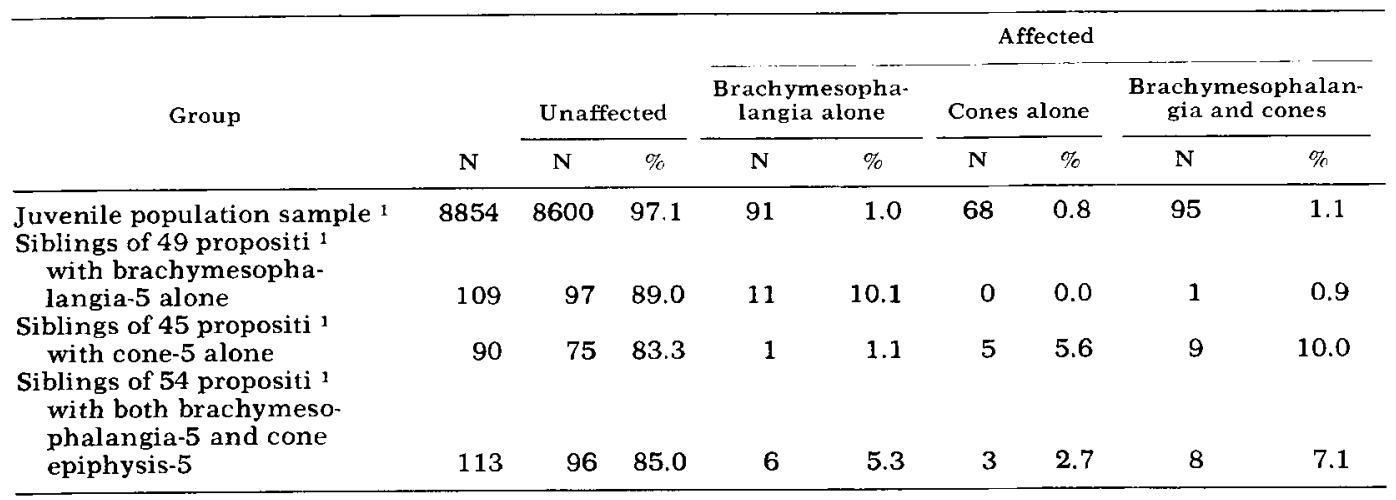

1 Age range 3.5-12.0 years, see text. Data include all racial groups.
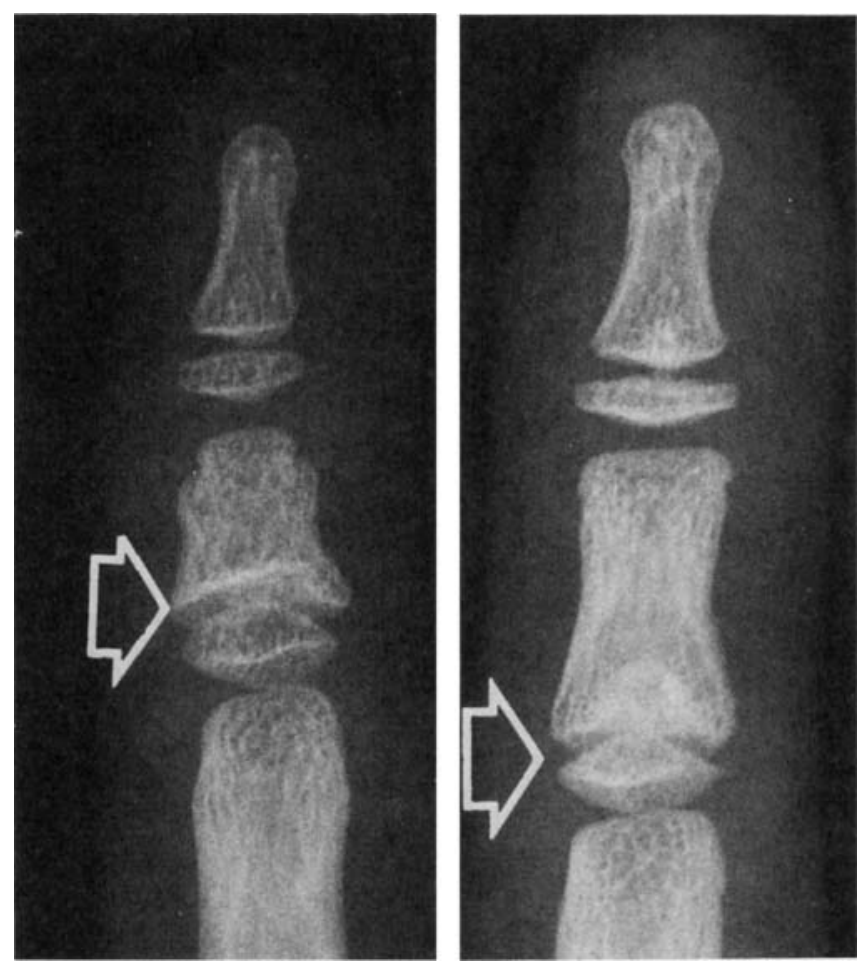

Fig. 1 Brachymesophalangia-5 with cone-shaped epiphysis (left) and a cone-epiphysis without brachymesophalangia (right). Brachymesophalangia-5 alone is inherited as an entity while the combination of brachymesophalangia-5 with a cone-shaped mid-5 is separately inherited and with a major influence of sex.

gia alone and in fact with but a single cone-epiphysis. So the phenotype brachymesophalangia alone appears to segregate as an entity in sibling analysis and with- out the commonly-reported association either in the propositi or their siblings.

In contrast, 90 siblings of 45 propositi with the cone-epiphysis of mid-5 alone 
showed brachymesophalangia alone, conesalone and brachymesophalangia and cones among the 15 affected members. Furthermore, 113 siblings of 54 propositi with both brachymesophalangia- 5 and the coneepiphysis of mid-5 also evidenced brachymesophalangia alone, cones alone and the combination brachymesophalangia and cone among their 17 affected numbers. Clearly, any combination involving cones (whether alone or in conjunction with brachymesophalangia) yields all three variants in the siblings, surely different from brachymesophalangia-5 alone, but not necessarily different from each other. Since the distribution of variants among the siblings of propositi with the cone-epiphysis alone and the combination of brachymesophalangia-5 and coneepiphysis mid-5 differs significantly neither when unaffected siblings are taken into account nor when affected siblings are alone compared in a three by two table, the most parsimonious explanation is that the cone-epiphysis (with or without brachymesophalangia-5) is differently and separately inherited from brachymesophalangia-5 alone.

Interestingly enough, brachymesophalangia-5 alone appears to be without the female predominance observed for brachymesophalangia-5 in general, for the cone-shaped epiphyses of mid-5 and for the cone-epiphysis trait in the foot (cf. Venning, '61; Hertzog et al., '68). The ratio of affected males to affected females (52:39) clearly contradicts any possibility of female predominance, even correcting for the male:female ratio from which the sample was drawn (4479:4375). On the other hand, cases of brachymesophalangia-5 with cones, like those with the cone-5 trait alone, are strongly biased in favor of females as shown by the highly divergent sex ratio, 45 males and 118 females. The differing sex-ratios suggest a genetic difference between the skeletal variant brachymesophalangia- 5 alone and the variant cone-epiphysis of mid-5.

The data we have here accumulated also enable us to exclude the cone-epiphysis as necessarily antecedent to brachymesophalangia-5. Since brachymesophalangia-5 exists without a cone-epiphysis in many cases (not quite the predominant situation), premature union of the cone is not a necessary determinant of the segmental shortening. Since the cone or peg may exist alone, with a middle phalanx of normal or even longer than normal length, the cone does not necessarily lead to segmental reduction such as has been postulated for the toes. A coneepiphysis of mid-5 and brachymesophalangia-5 seen together prior to union excludes premature union of the former as a necessary cause of the latter.

For the sibling data here presented, simple dominance may be excluded from consideration, even though examples of parent-to-child transmission have been reported in the literature. Either recessive inheritance or more complicated modes of transmission may be postulated, especially for the variant including cones, where the ratio of affected females to affected males is better than 2:1. Unfortunately, the number of affected individuals even in this extensive sample does not allow us to compare the proportions of affected siblings of either sex in relation to the sex of the propositus.

The sibling analysis, carefully using age-restricted siblings of similarly agerestricted propositi simplifies our understanding of the short middle segment of the fifth digit and the cone-epiphysis of mid-5. Brachymesophalangia-5 alone is apparently inherited as brachymesophalangia-5, without cones and without any demonstrable sex bias. On the other hand, cones (either alone or in conjunction with brachymesophalangia-5) are in herited as a complex (including brachymesophalangia-5) and with a 5:2 ratio of affected females over affected males. From our sibling-comparisons to date, brachymesophalangia-5 is at least two different inheritable traits in apparently-normal subjects, leaving open yet other possibilities in those with abnormal karyotypes and bone dysplasias.

\section{ACKNOWLEDGMENTS}

This study was supported in part by contract HSM-110-69-22 from the Nutrition Section, Center for Disease Control, Atlanta, Georgia and is the continuation of the same numbered project with Health Services and Mental Health Administra- 
tion. Judy Schweitzer and Gwendolyn Sandusky participated in the review of over 28,000 radiographs. Shirley $M$. Garrett was involved in the manuscript completion.

\section{LITERATURE CITED}

Abbie, A. A. 1970 Brachymesophalangy $V$ in Australian Aborigines. Med. J. Austral., 2: 736737.

Caffey, J., and F. N. Silverman 1967 Pediatric X-ray Diagnosis. Year Book Medical Publishers, Inc., Chicago.

de Iturriza, J. R., and J. M. Tanner 1969 Coneshaped epiphyses and other minor anomalies in the hands of normal British children. J. Pediat., 75: 265-272.

Garn, S. M. 1971 Human Races. Third Edition. Charles C Thomas, Springfield, IIl.
Garn, S. M, S. L. Fels and H. Israel 1967 Brachymesophalangia of digit five in ten populations. Am. J. Phys. Anthrop., 27: 205-210.

Giedion, A. 1965 Cone-shaped epiphyses (C.S.E.). Ann. Radiol., 8: 135-145.

Greulich, W. W. 1970 The incidence of dysplasia of the middle phalanx of the fifth finger in normal Japanese, in some American Indian groups, and in Caucasians with Down's syndrome. In: Environmental Influences on Genetic Expression. N. Kretchmer and D. N. Walcher, eds. U. S. Government Printing Office, Washington, D. C.

Hertzog, K. P. 1967 Shortened fifth medial phalanges. Am. J. Phys. Anthrop., 27: 113117.

Hertzog, K. P., S. M. Garn and S. F. Church 1968 Cone-shaped epiphyses in the hand. Invest. Radiol., 3; 433-441.

Venning, P. 1961 Radiological studies of variation in ossification of the foot. III. Cone shaped epiphyses of the proximal phalanges. Am. J. Phys. Anthrop., 19: 131-136. 